\title{
肉の消化に関する研究 \\ Studies on the Digestion of Meat
}

（3）牛肉の蛋白質消化に対する加熱の影響

(3) The Effect of Heat upon the Digestibility of Beef

(昭和 34 年 7 月 28 日受理)

$$
\text { 大 } \underset{\text { (Humio Ohtaka) }}{\text { 交 }} \text { 男 }
$$

The effect of heat upon the digestibility of lean beef and connective tissue in beef was investigated in vitro.

The beef boiled at $60^{\circ} \mathrm{C}$. or $95^{\circ} \mathrm{C}$. was digested to about the same extent as raw beef by pepsin. But, the digestibility of the beef autoclaved with water at $120^{\circ} \mathrm{C}$. was inferior to that of raw beef.

The digestibility of boiled or autoclaved connective tissue was greater than that of raw connective tissue. This would be due to the fact that boiled or autoclaved connective tissue contains a considerable amount of protein hydrolyzed easily by hydrochloric acid of the artificial digestive juice.

Grinley'1)は喠々の調理法で処理した牛肉の消化を人 間について実験した結果，調理法による消化率の差は余 りないといつている。また Grindley は牛肉を用いて， 生, 焙焼, フライおよび $80 \sim 85^{\circ} \mathrm{C} に 2 \sim 5$ 時間水煮した 場合についてベプシンによる人工消化試験をした結果， その差は余りないか，生肉は他のものよりも多少よいと 報告し，この理由として水溶性空素化合物が多少失われ るからたといつている。Talarico'文生の牛肉か㵭たも のとかわらない消化率を示すことを報告しているがこ れについて Haurowitz ${ }^{3)}$ は牛肉は䍃維性蛋白質に富む から熱変性してる消化性か湾らないと説明している。

著者は牛肉の蛋白消化と加熱の関倸について矢験した 結果, 牛肉を $60^{\circ} \mathrm{C}$ また $95^{\circ} \mathrm{C} に 1$ 時間水劣処理した るのは生の牛肉に比してその消化率は変らないか， 120 ${ }^{\circ} \mathrm{C}$ に 1 時間処理したものは消化率か;非常に低下寸るこ とまた牛肉の「すじ」の部分は妈理温度が高くなるに 従つて消化率が高くなるようであるか，人工消化試験に おける塩酸の作用を別にしてへブシンの作用についての 又比較すればこの場合る $100^{\circ} \mathrm{C}$ 以下の加熱によつては变 らないが， $120^{\circ} \mathrm{C}$ 加熱の場合にはその作用か低下寸るこ となどを認めたので，これについて報告する。

\section{実験 の方法}

牛肉の「すじ」をなるぺく除去した後，これを挽いて その $2 \mathrm{~g}$ を $100 \mathrm{cc}$ 容三角フラスコにとり，水 $20 \mathrm{cc}$ を加え 所定の温度で 1 時間加熱する。120 $\mathrm{C}$ に加熱する場合は
加圧鉒を用いた。なおフラスコは前以つて科量して 扣き，重量の羑により，水募後，蒸発した水分量を補給 する。次に水 $7 \mathrm{cc}, 0.2 \mathrm{~N} \mathrm{HCl}$ 溶液 $8 \mathrm{cc}$ および $2 \%$ ペプシ ン溶液 $5 \mathrm{cc}$ を加え， $38^{\circ} \mathrm{C}$ にて 24 時間消化する。消化後 $15 \% \mathrm{CCl} \mathrm{COOH}$ 窒液 $10 \mathrm{cc}$ を加之て未消化蛋白質を沈澱 させ，30分後に乾燥循紙にて濾過し，濾液の一定量につ いて Kjeldahl 法により窒素を定量する。消化率の算出 方法は前報4)と同じよ5にしだ。

牛肉の「すじ」の部分についても同様にして消化試験 を行つたが，試料中のコラーゲン望素の定量は H.C. Spencer の方法5によより肉「すじ」をアセトン処理して 風乾したものについて行つた。

\section{実験の 結 果}

\section{1）牛肉蛋白翼の加熱による消化率の変化}

生牛肉, $60^{\circ} \mathrm{C}, 95^{\circ} \mathrm{C}$ または $120^{\circ} \mathrm{C}$ にそれぞれ1時間 加熱した牛肉のペブシンによる消化は第 1 表の通りであ つた。なお，試料 I は暑殺後 5 日の肉であるか，その化 学的組成は水分 $74.3 \%$, 粗蛋白質 $24.0 \%$, 純蛋白質 21.4

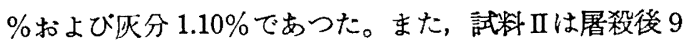
日の肉であるが，その化学的組成は水分 $73.4 \%$ ，粗蛋白 質 $23.8 \%$ ，純蛋白質 $20.8 \%$ 打よび扊分 $1.10 \%$ であつた。

ペプシンによる人工消化試験において塩酸の作用とへ プシンの作用とを区別するために，人工消化液にべプシ ンを加えることなく，その他は全く同じに処理して塩酸 による加水分解について調理しそれから数值の差により 
第 1 表 牛肉の加熱と蛋白消化率

\begin{tabular}{c|l|l}
\hline & \multicolumn{1}{|c|}{ 試 料 } & \multicolumn{1}{|c|}{$\mathrm{II}^{* *}$} \\
\hline 处理温度 & $83.1 \%$ & $82.7 \%$ \\
\hline 生 & 82.6 & 83.0 \\
$60^{\circ} \mathrm{C}, 1 \mathrm{hr}$. & 82.8 & 82.3 \\
$95^{\circ} \mathrm{C}, 1 \mathrm{hr}$. & 70.3 & 67.8 \\
$120^{\circ} \mathrm{C}, 1 \mathrm{hr}$. & .
\end{tabular}

* 屠殺後 5 日の牛赤肉

** 屠殺後 9 日の牛腿肉

ペプシンによる消化量を算出すれば第 2 表および第 3 表 のよ5になる。第 2 表は試料 I の場合，また第 3 表は試 料 II 場合である。

第 2 表 牛赫肉の人工消化試験に扣ける塩酸 扎よびヘプシンによる加水分解

\begin{tabular}{r|c|c}
\hline 处理 温度 & 塩酸の作用 & ヘプシンの作用 \\
\hline 生 & $-\%$ & $83.1 \%$ \\
$60^{\circ} \mathrm{C}, 1 \mathrm{hr}$. & 1.3 & 81.3 \\
$95^{\circ} \mathrm{C}, 1 \mathrm{hr}$. & 1.7 & 81.1 \\
$120^{\circ} \mathrm{C}, 1 \mathrm{hr}$. & 6.0 & 64.3 \\
\hline
\end{tabular}

第 3 表 牛腿肉の人工消化試験に打ける塩酸 扎よびペプシンによる加水分解

\begin{tabular}{c|c|c}
\hline 处理 温度 & 塩酸の作用 & ペプシンの作用 \\
\hline 生 & $1.3 \%$ & $81.4 \%$ \\
$60^{\circ} \mathrm{C}, 1 \mathrm{hr}$. & 1.3 & 81.7 \\
$95^{\circ} \mathrm{C}, 1 \mathrm{hr}$. & 1.6 & 80.7 \\
$120^{\circ} \mathrm{C}, 1 \mathrm{Sr}$. & 7.2 & 60.6 \\
\hline
\end{tabular}

生牛肉, $60^{\circ} \mathrm{C}$ なは $95^{\circ} \mathrm{C} に 1$ 時间水煮した牛肉にお いては，何れもその消化率に大した羑は認められないが $120^{\circ} \mathrm{C}$ に 1 時間加熟したものの消化率は極めて悪く，第 1 表によれば12〜15\% も低い値を示している。また，第 2 表および第 3 表よ.りペプシンの作周をみるとに $120^{\circ} \mathrm{C}$ 加筧した牛肉の消化は他のものよりも $17 \sim 21 \%$ む低くな つている。なお，塩酸によるが水分解は $120^{\circ} \mathrm{C}$ に水劣し

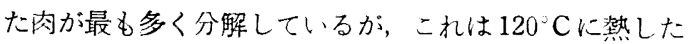
場合に肉の蛋白質が幾分低次のものに分解し，そのため に塩酸の作用を5けやすくなつたのであろう。

次に消化時間を長くした場合について, 生肉と $120^{\circ} \mathrm{C}$ に 1 時間加熱した肉とを比較すると第 4 表に示寸进りで ある。

人工消化試氮における塩酸の作用とぺ゚シンの作用を 区別するために，ヘプシンを加えることなく塩酸のみに よる調理值と上記消化率との数值の差から計算して求め た結果を示寸と第 5 表の通りである。

なお，この場合の試料 I は屠殺後 5 日の牛肉で, その 化学的組成は水分 $74.2 \%$, 粗蛋白質 $22.4 \%$ および死分 1.09\%であつた。また, 試料川は屠殺後 7 日の牛肉で,
第 4 表 牛肉蛋白質の消化率と消化時間の関係

\begin{tabular}{|c|c|c|c|c|c|c|}
\hline 工消化時间 & \multicolumn{2}{|c|}{24 時間 } & \multicolumn{2}{|c|}{36 時 間 } & \multicolumn{2}{|c|}{48 時間 } \\
\hline 処理温度 & $I^{*}$ & II $^{* *}$ & $I^{*}$ & $\mathrm{II}^{* *}$ & $I^{*}$ & II $^{* *}$ \\
\hline 生 & 84.4 & 81.9 & 84.5 & 84.4 & 91.0 & 90.8 \\
\hline $120^{\circ} \mathrm{C}, 1 \mathrm{hr}$. & 75.2 & 68.2 & 81.4 & 73.4 & 86.2 & 78.8 \\
\hline
\end{tabular}

第 5 表人工消化試験に指りる塩酸 把よびヘプシンの作用

(\%)

\begin{tabular}{|c|c|c|c|c|c|c|c|}
\hline \multirow{2}{*}{ 処 } & \multirow{2}{*}{ 温 } & \multicolumn{2}{|c|}{24 時 間 } & \multicolumn{2}{|c|}{36 時 間 } & \multicolumn{2}{|c|}{48 時間 } \\
\hline & & $I^{*}$ & $\Pi^{* *}$ & $I^{*}$ & $\mathrm{II}^{* *}$ & $I^{*}$ & II ** $^{* *}$ \\
\hline & 生 & 3.6 & - & 4.0 & - & 4.7 & - \\
\hline 监 毁 & $120^{\circ} \mathrm{C}, 1 \mathrm{hr}$ & 11.0 & 6.3 & 12.1 & 5.9 & 12.3 & 5.9 \\
\hline & 生 & 80.8 & 81.9 & 80.5 & 84.4 & 86.3 & 90.8 \\
\hline & $120^{\circ} \mathrm{C}, 1 \mathrm{hr}$ & 64.2 & 61.9 & 69.3 & 67.5 & 73.9 & 72.9 \\
\hline
\end{tabular}

その化学的組成は水分 $74.5 \%$, 粗蛋白質 $23.7 \%$ 扰よび死 分 $1.10 \%$ であつた。

$120^{\circ} \mathrm{C}$ に加熱した肉も消化時間を長くすれば粫次消化 されていくが，対照にくらべるとその消化率は極めて悪 かつた。

\section{2）牛肉のすじの蛋白雷の加熱による消化平の变化}

牛肉の「すじ」をとり，これをできるたけ細切して用 いた。屠殺後 10 日のもので, その化学的組成は水分 $62.2 \%$ ，粗蛋白質 $33.5 \%$ 扰よび灰分 $1.20 \%$ にして，コラ ーゲン窒素は全呿素中 $90.2 \%$ であつた。前と全く同様に して消化試験を行つた結果について，その消化率，塩酸 の作用およびペプシンの作用として示せば第 6 表の通り である。

第 6 表 牛肉の「すじ」の消化

\begin{tabular}{c|c|c|c}
\hline 处理温度 & 消化率 & 塩酸の作用 & $\begin{array}{c}\text { ペプシン } \\
\text { の作用 }\end{array}$ \\
\hline 生 & $59.4^{\%}$ & $19.3^{\%}$ & $40.1^{\%}$ \\
$60^{\circ} \mathrm{C}, 1 \mathrm{hr}$. & 68.5 & 26.2 & 42.3 \\
$95^{\circ} \mathrm{C}, 1 \mathrm{hr}$. & 76.4 & 32.7 & 43.7 \\
$120^{\circ} \mathrm{C}, 1 \mathrm{hr}$. & 84.4 & 51.5 & 22.9 \\
\hline
\end{tabular}

これによると肉の「すじ」は水煮温度の亮いすの程よ く消化されるが，へプシンの作用をみると $120^{\circ} \mathrm{C} に$ 処理 したもの以外は大差なく， $120^{\circ} \mathrm{C}$ に加㷫したものだけが 低くなつている。なお，塩酸による加水分解度もかなり 高いのでこの点について検討するためにゼラチンにつ いて塩酸による加水分解を調理した結果，第7表のよう になつた。 
試料の暂は前の聅 駼の場合と固形分量 を大体同じよににす るために $1 \mathrm{~g}$ を用い たか，その他は全く 同様にして行つた。 笑鍳に用いたぜラチ ンの化学的組成は水
第 7 表 せラチンの塩酸 に上る加水分解

\begin{tabular}{|c|c|}
\hline 处理温度 & 加水分解度 \\
\hline 対 & $62.9 \%$ \\
\hline $60^{\circ} \mathrm{C}, 1 \mathrm{hr}$. & 66.8 \\
\hline $95^{\circ} \mathrm{C}, 1 \mathrm{hr}$. & 69.4 \\
\hline $120^{\circ} \mathrm{C}, 1 \mathrm{hr}$. & 70.5 \\
\hline
\end{tabular}

分 $16.8 \%$ および全空素 $15.0 \%$ であつた。

これによるとゼラチンは $38^{\circ} \mathrm{C}$ において塩酸によりか なり加水分解されることがわかつたので，肉の「すじ」 る水背してゼラチン化した場合には塩酸によりかなり加 水分解されるものと思われる。

\section{考察}

牛肉の蛋白質は人工消化試験によれば $60^{\circ} \mathrm{C}$ または 95 ${ }^{\circ} \mathrm{C}$ に 1 時間水煮しても生のものと变らない消化率を示 した。また，塩酸の作用を別にしてべブシンの作用につ いても $60^{\circ} \mathrm{Cまたは} 95^{\circ} \mathrm{C}$ に水煮した牛肉は生肉と同じ程 度に作用を受けだ。

牛肉の「すじ」については高温に加熱した場合に高い 消化率を示すよ5であるが，ヘブシンの作用について は $60^{\circ} \mathrm{Cまたは} 95^{\circ} \mathrm{C} に 1$ 時間水煮したものは生のものに 比し余り変りがなかつた。

Talarico') は生の牛肉と惹沸した牛肉の酵素による消 化が大差ないことをいつているが，F. Haurowitz ${ }^{3)}$ は この理由を牛肉にはミオシンのよ5な䋞維状蛋白質が多 く含まれるためであると説明している。すなわち，Linderström-Lang ${ }^{6)}$ および Lundgren ${ }^{7} に$ にると球状蛋白 質は自然状態においては酵素の作用を受けにくく，加熱 变性を受けた場合に酵素の作用を受けやすくなる。この 蛋白質においてはへプチド連鎖が幾重にも折り重なつて 網状組織をなしてるため，自然状態においては醉素の作 用点か球状分子の中にあり，従つて醉素の作用を受けに くいのであるが，加熱変性されるとそのぺブチド連鎖が より簡単な結合になつていくので酵素の作用を受けやす くなるのであろ5。故に，べブチド連鎖の伸展している ような織維状蛋白質においては变性の前後において酵素 の作用に余り差異がないものとしている。

また, Haurowitz ${ }^{3)}$ はコラーゲンが加熱变性の場合， 硣素の作用を受やすくなるのはコラーゲンがゼラチンに 移行するためであるとしているか，この赛験においても 同様の結果となつている。たたし，人工消化試験におい て塩酸の作用を別にし，プヘシンの作用のみについてみ るとコラーゲンすをた加熱温度が $100^{\circ} \mathrm{C}$ 以下なれば醭素 炕り受ける作用に大差のないことが示されている。
しかるに牛肉および牛肉の「すじ」を $120^{\circ} \mathrm{Cに} 1$ 時間 加熱したものについて人工消化試験における塩酸の作用 を別にし，ペブシンの作用をみると生肉に比し明らかに その作朋が低下している。このことは LintderströmLang 拈よび Lundgren の説明とは別に蛋白質はある 温度以上に加熱变性を受けるときは酵素により作用され にくくなる原因のあることを示している。

Rice および Beuk ${ }^{8}$ は蛋白質の栄責価に対する加熱の 影瞕について解説しているが，これによると一般に $100^{\circ}$ C 以下の加熱では消化率または生物価の低下は余りない が，これ以上の温度に加熱する時は生物価が低下し，特 に炭水化物と共存する場合にその影暨のあることを述べ ている。カゼイン9)执よび卵白(10)などについても同様 の報告があるが，この原因については更に暙験検討した w。

要 約

牛肉を $60^{\circ} \mathrm{C}$ たは $95^{\circ} \mathrm{C} に 1$ 時間水煮しても， ゚゚プシ ンにより，生牛肉と同じように消化された。しかし， $120^{\circ} \mathrm{C}$ に 1 時間オートクレーヴ中で加熱した場合はその 消化率が著しく低下した。

牛肉の「すじ」の蛋白質は加熱により生の場合よりる よく消化されるようになつたか，人工消化試験における 塩酸の作用を別にして，ぺプシンの作用のみについてみ ると， $60^{\circ} \mathrm{C}$ また $95^{\circ} \mathrm{C} に 1$ 時間水惹したものに対して は，生の場合と変りないが, $120^{\circ} \mathrm{C}$ に加熱したものに対 してはその作用が低下するようであつた。

終始，御指導御鞭婞を賜わりました恩師佐々木林治郎 先生に樑く感謝の意を表します。

$$
\text { 文献 }
$$

1) H. S. Grindley: U.S. Dept. of Agriculture, office of Experiment Stations, Bulletin 193 (1907)

2) J. Talarico: Comt. Rend. Soc. Biol. 68, 662, 932 (1910)

3) F. Haurowitz: J. Biol. Chem. 157, 621 (1945)

4) 佐々木，大高－栄意と食糧 12, 244 (1959)

5) H. S. Spencer, S. Morgulis, and M. W. Violet: J. Biol. Chem. 120, 257 (1937)

6) K. Linderström-Lang: Annual Review of Biochemistry 8, 45 (1939)

7) H. P. Lundgren: J. Biol. Chem. 138, 293 (1941)

8) E. E. Rice and J.F. Beuk: Adv. in Food Research IV. 233 (1951)

9) N. R. Eldred and G. Rodney: J. Biol. Chem. 162, 261 (1945)

10）木咲, 越智：同志社女子大 9,39 (1958) 日化覧 33, 1333 (1959)

(荻城大学農学部) 